\title{
STRUCTURE AND DYNAMICS OF VERBAL CONFLICT SITUATION (BASED ON THE ENGLISH LANGUAGE DISCOURSE)
}

\author{
Larysa Chayka ${ }^{1}$
}

\begin{abstract}
The article provides the results of the verbal conflict analysis based on the English language dialogical discourse highlighting the problems related to its definition, structure and dynamics. The paper discusses a series of issues concerning the verbal conflict which is characterized by linguistic manipulation, i.e., by using language features and principles of its application on the purpose of hidden influence on the addressee in the right direction for the addresser. The article offers definitions of concepts of the verbal conflict situation, its phases and components, identifies actual and potential kinds of the verbal conflict, depicts individual images of the verbal conflict situation. The article considers the ideas of communicators of themselves and their partners on conflicting speech communication about the goals, opportunities, social characteristics and mental state; on the environment in which the verbal conflict occurs; on the code of communicative act; on the communication channel through which communicative interaction is carried out. The work characterises two types of actions that are part of a system of counter-actions in the context of emotional states, the purpose of which is to block the intentions of another communicator directly or indirectly and to achieve the ultimate purpose. Direct or indirect going out of the verbal conflict situation is characterised. Among the various manipulative communicative steps there are the tactics which are known to psychologists and specialists in the theory of communication, such as: masking one's own intentions; outright misinformation of the enemy; false consent; enticement; expectation; demonstration of false and true goals (distraction of attention); bluff, etc. Escalation of the verbal conflict is treated as clashing on the subject-activity basis or on the personal basis. Several variants of the actual course of the conflict speech interaction are distinguished. Finally, we offer some concluding remarks and suggestions for further investigations.
\end{abstract}

Keywords

Verbal Conflict, Structure, Dynamics, Manipulation, Addresser, Addressee, Communicative Act, Communication Channel, Escalation.

1. Introduction. The modern neoliberal multipolar world, the world of risks and dynamics, the world of the so-called "controlled chaos" generates a variety of conflicting interests and their influence on the linguistic environment, which can lead to various conflicts. Among the latter ones, verbal conflicts gain specific importance.

The object of the article are the utterances actualizing conflict senses in the modern English-language discourse. The subject of the paper is verbal conflicts as a peripheral side of human communicative activity. "The verbal conflict" term is treated widely: as such a violation of the process of human communication through the natural human language, in which one of the communicants does not understand the other one partially or completely, negatively relates to his/her manner of speech behavior, verbal-cognitive base, or to the signs used in the act of communication. This formulation of the problem is based on the belief that the social, cultural and ethnic belonging of the communicant, his/her psychic state requires certain forms of expressing intentions; linguistic units and con-

\footnotetext{
${ }^{1}$ L. V. Chayka, PhD, Associate Professor, Ukraine, 01601, Kyiv, Triokhsviatytelska St., 4 Research and Educational Center of Foreign Languages, National Academy of Sciences of Ukraine, Email: ChaykaLV@nas.gov.ua. ORCID: orcid.org/0000-0002-7729-337X

${ }^{2}$ Zirka 2005, 209
}

structions manifestate this affiliation (or, at least, are potentially capable of such a manifestation), which, in some contexts of any level, leads to violating the process of social communication. The purpose of the work is to describe and analyze verbal conflicts from the speech activity theory's point of view. In order to study this phenomenon comprehensively one needs to find the answer to the question: how and to what extent is the internal system of the language capable of manifesting extralinguistic aspects of communicative human activity, leading to violations of the communication process?

2. Background and motivations. Prof. Zir$\mathrm{ka} \mathrm{V}$. V. points out that among the stimuli that cause a person's emotional reaction, the word occupies the most important place and it has an impact on man many times more than any other factors. The semantic content of the word, its meaning causing certain associations acquires here a particular significance. The word makes quite a strong and specific impact on a person. The purpose of communication during a conflict is to influence consumers, to convince them of the correctness of what is said with the help of the words, which can cause the necessary thoughts and feelings ${ }^{2}$.

The fact is that people always program each other; a psychologically strong person suppresses the will of the psychologically weaker one. On the example of advertising, Feofanov O. A. stresses that manip- 
ulation is not a new phenomenon, however, initially advertising informed about goods and services, and now it has become a sophisticated system of psychoprogramming the masses and manipulating their needs. "Psychoprogramming" should not be interpreted as a straightforward, explicit impact, but as a hidden, gradual and systematic influence on the psyche of people, primarily on the emotional and unconscious spheres ${ }^{3}$.

In our opinion, it is appropriate to quote Yu. Tynyanov's thoughts about the power of the word, who wrote that the printed documents should not be treated with piety, because they lie as people do. Words (and not just printed ones) have a magical authority over people. Sometimes they have an unlimited credit. Propaganda and agitation are primarily hypnosis of the words, based on the instincts of the masses. The masses follow the words ${ }^{4}$.

Treating the language as "the loaded weapon" D. Bollinger emphasises that the language is not only a means of communication, but it is also a means of separation, it is not only a means of self-expression, but it is a means of manipulation as well, it is not only a means of liberation, but it is also a means of enslavement by language stereotypes. Communication and transfer of information among people take place not for the sake of themselves, but for the achievement of certain goals 5 .

\section{Methodology.}

3.1. The material of the research. The research material consists of 1750 utterances realizing the verbal conflict situation selected from 14 modern British and American prose works of the whole amount of 3294 pages. In addition to this main corps of selection, artistic works of the other time periods, journalistic texts, etc., as well as lexicographical and reference sources were used at certain stages of the study.

3.2. Methods. The general scientific methodological foundation of the work is an integrative activity approach based on the postulates of synergetics and the theory of dynamic chaos ${ }^{6}$. Within the limits of a discursive paradigm, the mentioned methodological foundation appears as a set of principles of anthro-

\footnotetext{
${ }^{3}$ Feofanov 2000, 134

${ }^{4}$ cited by: Borisov 2001, 38-39

${ }^{5}$ Bollinger 1980, 123

${ }^{6}$ G. Nikolis, O. M. Knyazeva; Chaos and Order, From Simplicity to Complexity et al.

${ }^{7}$ O. S. Kubryakova

${ }^{8}$ Frolova 2009

${ }^{9}$ Shevchenko 2017

${ }^{10}$ Petlyuchenko 2009

${ }^{11}$ Slavova 2012

${ }^{12}$ K. M. Laurindsen, E. E. Sweetser

${ }^{13} \mathrm{~N}$. Bohr

${ }^{14} \mathrm{~V}$. Heisenberg
}

pocentrism, functionalism, explanativity and expansionism ${ }^{7}$. In addition, the methodology of the research integrates principles of communication and discourse analysis according to which cognitive, communicative, pragmatic and discursive vectors of studying verbal objects are combined ${ }^{8,9}$, the methods of investigation also include elements of linguopersonology $^{10,11}$ accentuating inseparable ties of collective and individual principles in the discursive interaction.

The general methodological guides of synergetics and the theory of dynamic chaos enabled us to analyze the discourse entities as indistinct categories ${ }^{12}$, whose borders are blurred; as phenomena that integrate the virtual (mental) and material (verbal) plans, demonstrating the interaction of the system and the environment. The principles of complementarity ${ }^{13}$ and uncertainty ${ }^{14}$ are formed on the basis of these methodological guides. This fact allows us to study the linguocognitive and speech component of the regulatory potential of the verbal conflict in a certain way, as well as to identify the characteristics that the utterances implementing this strategy acquire in the context of the dialogue, the text, the speech act, etc.

Anthropocentrism of the research is oriented to consider the verbal conflict as a psycho-mental and speech activity of man, aimed at regulating relationships with the interlocutor.

Expansionism and explanativity are interrelated in the research, since involving the data of various linguistic theories and taking into account the achievements of conflictological experience can provide argumentation and explanatory power to analyse the verbal conflict speech interaction.

Functionalism is a priority principle of this work, because it is the regulatory function, in particular the interpersonal one, that acts as a "parameter of order", which allows us to arrange the completely chaotic set of conflictogenic verbal manifestations.

The methodology of the study led to the expediency of using a comprehensive number of methods, in particular methods of linguistic semantics and linguistic pragmatics, cognitive and communicative linguistics, and discourse analysis, applied in the light of the tasks set. The method of decomposition of existing theories and the synthesis of their certain utterances was used to clarify a number of discourse concepts, to define the concept of the verbal conflict and to find out the correlation between concepts of conflict and confrontation. The method of preferential selection was applied when choosing sources of illustrative material; methods of contextual analysis and cognitive-discourse interpretation were implemented to identify utterances as actualizers of the verbal conflict. The continuous sampling method was employed to form a research frame; some elements of cognitive-semantic analysis were proved necessary to reveal the scope and content of knowledge about the verbal conflict by representatives of the English 
language linguistic culture. On the same purpose, as well as for the schematic presentation of the verbal conflict situation in the discrete and process aspects, the method of frame modeling was applied. Methods of conversion analysis, text interpretation, pragmatic and semantic speech act analysis became essential when researching the actualized knowledge about the verbal conflict embodied in the English language dialogical discourse; elements of quantitative analysis allowed to find out the specific role of speech strategies and tactics of the verbal conflict in different types of the English-language dialogical discourse.

4. Results and Discussion. Not claiming to be original, we affirm the transparent truth that the verbal conflict is also characterized by linguistic manipulation, that is, by using language features and principles of its application on the purpose of hidden influencing the addressee in the right direction for the addresser. "Hidden" here means unconscious impact on the addressee, when the speaker uses the hidden language features in order to impose a certain idea of reality that does not coincide with the picture that the addressee could form on his/her own. In such cases, language is used as "a means of social power"15.

The problem of interpreting the phenomenon of "conflict" still remains unsolved. For example, scholars A. Ya. Antsupov and A. I. Shipilov analyzed more than 50 of its definitions and tried to summarize them in accordance with the methods of interpretation by different researchers. However, the scientists were compelled to summarize that the overwhelming number of definitions reveals either the narrowness or the vulnerability and therefore does not correspond to the description of all kinds of conflict ${ }^{16}$.

Other investigators reached similar results, e.g. L. M. Gerasin, M. I. Panov and N. P. Osipova agree with this conclusion, emphasizing that the basis of any conflict is a contradiction that has a system-forming value both for certain types of conflict and for different levels of their study. Therefore, this understanding causes problems in their interpretation ${ }^{17}$.

Consequently, we will agree to treat the verbal conflict as such a violation of the process of human communication with the help of natural language, in which one of the communicants does not understand the other partially or completely, negatively relates to his/her manner of speech behavior, the verbal-cognitive basis or to the signs used in the act of communication.

\footnotetext{
${ }^{15}$ Вакаг 1979, 131-169; 131-169

${ }^{16}$ Antsupov\&Shipilov 2008, 31-35

${ }^{17}$ Herasina, Panov\&Osipova 2002, 137

${ }^{18}$ Dontsov\&Polozova 1980, 124

${ }^{19}$ Borisevich 2003, 13

${ }^{20}$ Borisevich 2002, 186

${ }^{21}$ Aksyonenko 1985, 9
}

The originating of the verbal conflict situation involves two phases. During the first of these, the speaker (for the most part) uses a linguistic unit or a structure, which, for one reason or another, can be considered as conflictogenic by the addressee. During the second phase, the addressee interpreting the addresser's speech pays attention to the inconformity of the language unit or the structure used by the speaker and his/her own ideas about the course of speech communication. Then we can state that there is a verbal-conflict situation in a communicative act, with its structure, which is treated as "a list of necessary and sufficient elements that characterize the conflict at a one-time static cross section"18.

In our opinion, the structure of the verbal conflict situation includes the following components:

- presence of at least two contrary parties of a communicative act, which perform a speech contact aimed at achieving communicative intention by one of the communicants at the expense of destroying the goals of another communicator and combined with paralinguistic and extra-linguistic confirmation of the addressee and the addresser ${ }^{19}$;

- availability of the prerequisites for the emergence of a dynamic situation in the verbal conflict in the form of a conflictogenic factor, which is a special catalyst for misunderstanding or negative evaluation of speech by at least one of the communicants, i.e. for the emergence of socio-psychological situation of the conflict type of speech interaction (presence or absence of other speakers and listeners, the place and time of the communicative act, etc.);

- possibility of using tactical communicative moves by one (or by all) communicators with the aim of making the speech impact on the contrary party in the desired direction ${ }^{20}$.

Since the conflictogenity of the speech interaction may not be realised by the communicants during a certain period (from one to several communicative steps), the situation from the introduction of the conflictogenic factor to its perception as the conflict-related, can be called a potential verbal conflict. In contrast to the potential conflict, an actual conflict of a verbal nature can be generated when the partners of the communicative act realize the situation to be conflictogenic. "Probably the state when both (or several) participants of the conflict situation are fully aware of it and represent the objective role of each one in the conflict, is ideal and, generally speaking, abstract, - psychologists say. In fact, awareness of the conflict always carries elements of subjectivity and is therefore, to some extent, distorted, and this can not but influence upon the course of the conflict and its overcoming"21. Since verbal conflicts are a kind of socio-psychological conflicts in general, we can rely on this statement as the methodological one, extrapolating it to linguistics. 
Inadequacy of depicting the verbal conflict situation allows to assert that in its course a communicant (or communicants) creates individual images of the verbal conflict situation ${ }^{22}$, which determine the conflicting behavior of the addresser and the addressee. On creating the image of the verbal conflict situation, the reality is distorted. Therefore, the "gap" between the ideal picture of the verbal conflict situation and its reality stimulates the conflicting speech behavior of the communication participants both towards the removal of the conflictogenic factor and the verbal conflict escalation, up to stopping the act of communication or up to moving it to non-verbal rails. Both in the first and in the second case, certain manipulative dialogue tactics can be used stimulating or suppressing the verbal-conflict interaction.

Awareness of the verbal conflict situation consists of ideas "I - non-I", "conflict environment", "code of communication", "channel of communication"23. Thus, these ideas are "the internal pictures of the situation" ${ }^{24}$. They include the idea of communicators about themselves and their partners of conflicting speech communication on the goals, opportunities, social characteristics and mental state; on the environment in which the verbal conflict occurs; on the code of communicative act; on the communication channel through which communicative interaction is carried out. In the case of the verbal conflict, all the proposed four types of ideas arise during the verbalization of the intentional utterance, creating a pole of conflict pressure in the form of the communicator, since the actual lack of understanding a speech unit or its negative estimation take place mainly when the addressee percepts this verbalized intentional speech unit $^{25}$. It is worth adding that in order to treat the situation as a verbal conflict, one should remember that emotional support is practically always inherent here, and the communicators' emotional states occuring at this moment are included in the conflict genesis and in this way, they influence its course and solution.

After the conflict factor is introduced and the situation is consciously perceived as conflictogenic by at least one of the communicants (i.e., the situation is recognized to be significant, and the positions of the communicators look incompatible at this stage), the actual development of the conflict begins. In this case, there are two possible types of actions that are part of the counter-actions' system in the context of emotional states. Their purpose is to block the intentions of another communicator directly or indirectly and to achieve the ultimate purpose:

1. Direct or indirect going out of the verbal conflict situation. The direct going out of the verbal con-

\footnotetext{
${ }^{22}$ Borisevich 2003, 187

${ }^{23}$ Chayka 2011, 170-174

${ }^{24}$ Petrovskaya 1977, 130

${ }^{25}$ Borisevich 2003, 188
}

flict should be treated as the refusal of one of the communicants from any of the forms of conflict speech interaction ("reconciliation", "escalation"), i.e. ceasing the conflict type of speech communication after introducing the conflictogenic factor and realising the conflict situation. The factors of this phenomenon may be various. Let us consider the following text as an example:

"One hot day, we traveled around the north of Scotland and stopped the car to give our old collie a chance to get some air. Breathing heavily and sticking his tongue out, he lay down on a grassy knoll, and my husband laid out a map over the hood of the car and, leaning his head on his hands, went into studying it. A car drove up.

- Is he feeling bad? - asked the driver carefully. How can I help you?

"Oh, no," I replied. - Just getting old. At one time, he was pulling me out of the car by force, just to tumble in the grass.

The stranger carefully looked at me and hurried away. He did not notice our dog" ("Reader's Digest").

The kind of the verbal conflict depicted in this simple story was well known to ancient Romanian comedians as a quid pro quo technique. Another striking example of this method is the dialogue between Lyconides and Euclio of Plautus' comedy "The Pot of Gold". In this case, the essence of the verbal conflict is contained in the fact that the communicants thinking they are talking about the same thing actually mean quite different things. Therefore, the first communicant asks how the woman's husband feels, and she answers him having her dog in mind. Then the first communicant interprets her reactive replica as the answer concerning her husband (i.e., concerning a completely different utterance's referent), which may insult his English sense of Victorian restraint in sexual matters. He stops communicating and leaves. The second communicant introduces the conflictogenic factor ("depravity"?); the first one treats the situation as conflicting. Meanwhile, the first communicator does not continue the dialogue. Otherwise it would be possible to predict the use of sequences to explain the meaning of the second communicant's speech unit in order to further clarify the situation and eliminate the conflictogenic factor, or by using the statement "Shame on you!", which would initially lead to the verbal conflict escalation and he ceases communication going out of the conflict situation. The reason for this is psychologically simple: the further communication is inappropriate, the conflictogenic factor is insignificant (the second communicator is a stranger, his communicative intention contradicts the communicative intention of the first communicator, mainly at the verbal level), the degree of conflictogenicity is rather low. There is no need to maintain communication. Such varieties of the verbal conflict 
are rather common, but they are quite simple and not interesting, because the very subject of controversy and the volume of doubtful "victory" may not justify the spending of speech actions.

Another variant of ending the verbal conflict is connected to the fact that one of the communicants realises that the "means" are not sufficient for either escalating or overcoming the verbal conflict:

- insufficient information;

- impossibility of convincing arguments at the moment (e.g. it can be linked with subordinate relations such as "boss - subordinate");

- lack of one of the communicants' own speech means to develop and resolve the situation of the verbal conflict (e.g., poor knowledge of the language by a foreigner).

Signal replicas in such cases will be reactive statements of the kind "I did not know", "I will check", "I will clarify this issue with specialists," etc.

The third way out of the verbal conflict is a manipulative speech act, a trick for the purpose of radical change in the situation in favor of the manipulator: in this case, the addresser verbally informing about a certain fact seeks to achieve quite a different purpose. The manipulative speech act is different from the literal (direct) speech act ${ }^{26}$ and from non-literal speech act ${ }^{27 ; 28}$, since Maxim of Quality ("Do not say what you believe to be false. Do not say that for which you lack adequate evidence.") and Maxim of Relation ("When engaged in conversation, the Maxim of Relation requires you to be relevant") are violated during speech generation ${ }^{29}$. Thus, if in the non-literal speech act, the addressee can deduce those side-related content nuances, which the addresser inserts into these statements, based on socio-legal canons of the given language and cultural community from the addresser's message, then the content of the manipulative speech utterance remains hidden for the addressee. In this case, the verbal conflict associated with the listener is generated, the verbal conflict situation of misunderstanding arises, and the speaker reaches his/ her communicative purpose and goes out of the conflict at the expense of the fact that the addressee is not able to understand the true intentions of the addresser. Here is an example of the manipulative speech interaction: "Are you going fishing in the morning? - Wanna go with me? - No, leave the keys to your room, please, I need it."

Among the various manipulative communicative moves allowing indirectly to escape the verbal con-

\footnotetext{
${ }^{26}$ Searle 1975, 59-82

${ }^{27}$ Vanderveken 1991, 381

${ }^{28}$ Searle 1975, 73

${ }^{29}$ Grice 1975, 180-181

${ }^{30}$ Krogius 1979, 219

${ }^{31}$ Schelling 1980, 217
}

flict without its escalation, one can mention the tactics which are known to psychologists and specialists in the theory of communication for a long time: masking one's own intentions; outright misinformation of the enemy; false consent; enticement; expectation; demonstration of false and true goals (distraction of attention); bluff, etc. ${ }^{30}$. Their specificity is explained by the fact that manipulations do not involve a struggle and an open conflict, i.e. they do not lead to a peak of the conflict.

2. Escalation of the verbal conflict. We will agree to treat the escalation of the verbal conflict as clashing on the subject-activity basis or on the personal basis. This clashing is expressed in growing losses of speech devices against the background of emotional states, with increasing conflict level and corresponding decrease in the level of connection between the speaker and the listener, up to the transition of the conflict to non-verbal rails.

The peak of the verbal conflict is the state of the communicative act that is realised by all the communicants, when the crisis of the verbal conflict comes to an end with its further breaking-up - intercession, cessation of communication, and its development into the non-verbal conflict.

The complexity to describe an escalative verbal conflict lies in the fact that, as T. Schelling states, "in addition to their direct function, e.g. contributing to the achievement of their goals ..., the actions also include the moments of communication between the parties and play an important information role in this regard... The words are often cheap; the participants prefer to judge the intentions, values, the possibilities of the contrary parties, primarily not by their words, but by their actions. Similarly, they often resort to actions to convey their own intentions, assessments, and demonstrate their own capabilities to the contrary party"31.

We can distinguish several variants of an actual course of conflict speech interaction during the verbal conflict escalation:

a) reaching the the conflict peak and its gradual decline (i.e. further complete or incomplete going out of the conflict). This way out of the verbal conflict could also be called the way of "bargaining" or "negotiating". On realizing the situation to be a conflict one after its escalation, the communicants carry out its analysis and determine a set of conditions that should help to resolve the situation of the verbal conflict. At the same time, the main principle is the principle of differentiation, the separation of communicators from each other, the desire to defend their initial convictions and communicative goals. Then, differentiation is changing for integration, correction of one's own intentions and searching mutually acceptable common problem solving. In the process of integration, there is also a modification of emotional settings relative to each other; consequently, the 
mutual subject-activity settings change: awareness of the problem's significance and the level of awareness about the goals and actions of the contrary party ${ }^{32}$. As a result, the verbal conflict gets its full or partial solution after discussing the problem;

b) reaching the conflict peak and ceasing the act of communication by one or by all of its participants. In this case, the communication settings of the addresser and the addressee are interpreted as incompatible, and spending the means for their modification is treated as inappropriate. This type of going out of the verbal conflict is different from the previous one, exactly, by the phase of ceasing communication, not on realising the situation as a conflict, but after a certain amount of mutual speech actions (often invective) leading to the conflict peak and to another recognition of the incompatibility of the addresser's and the addressee's communicative intentions and the incompatibility of using the "bargaining - negotiating" strategy;

c) reaching the the conflict peak and moving it to non-verbal rails. The cessation of communication after the awareness of the conflict peak is the way out of the verbal conflict characterized by the cessation of interpersonal interaction. In contrast, there is the third, rather painful type of escalative verbal conflict, which is inherent in the continuation of interaction, but with the help of non-verbal means. These include using fists or returning to the conflict situation, but this time as if at a distance. It can be further (after the act of communication) defaming, bullying of the opponent and other methods by the principle of "dirty edging". In our opinion, there is no need to give examples that have been well described in researches on practical psychology. According to the list of bullying methods (consisting of 90 ordinary and 95 special ones), we refer to the paper by P. S. Taranov ${ }^{33}$.

5. Conclusion. In this article, we have presented a comprehensive survey of the existing theories and approaches to verbal conflict research and outlined its future perspectives. Our critical overview leads us to suppose that the state of the art of verbal conflict study is a mosaic of theories and ideas that successfully complement each other. Many contemporary investigations are devoted to verbal conflict and its linguistic manifestation. It should be emphasised that verbal conflict identification and processing procedures are likely to gain even greater interest in the future.

Thus, the conflict type of speech interaction has a great number of varieties that we have tried to accumulate in a dynamic scheme. The analysis of the material shows that the peak of the conflict is just a dynamic phenomenon, a process with a certain quantity and quality of components. At the same time, in an instant version, the structure of the verbal conflict that is available at all stages of its dynamics is distinguished. The dynamics and stability of the verbal conflict also determine the functionality that the verbal conflict acquires in the act of communication.

\section{BIBLIOGRAPHY}

Аксененко С. Е. Осознание конфликтной ситуации и общение. Теоретические и прикладные проблемы психологии познания людьми друг друга. Тезисы докладов. - Краснодар: Изд-во Кубанского университета. 1975. - С. 9-11.

Анцупов А. Я., Шипилов А. И. Конфликтология: учебник для вузов. 3-е изд. - СПб.; М.; Х.; Минск: Питер. 2008. - 490 с.

Борисов Б. Л. Технологии рекламы и PR: учебное пособие. - Москва : ФАИР-ПРЕСС, 2001. - 624 с.

Борисевич В. В. Образы вербально-конфликтных ситуаций. Культура народов Причерноморья. 2003. № 44. -

Симферополь: Таврический национальный университет им. В. И. Вернадского, 2003. С. 186-190.

Борисевич В. В. Значення соціальної ролі комуніканта в генезі вербального конфлікту. Мова та історія: Періодичний збірник наукових праць. - Київ, 2002. - Вип. 59. - С. 13-15.

Герасіна Л. М., Панов М. І., Осіпова Н. П. Конфліктологія: навч. пос. - Харків: Право, 2002. - 256 с.

Донцов А. М., Полозова Т. А. Проблема конфликта в западной социальной психологии. - Психологический журнал. - Т. 1. - № 6. - 1980. - С. 119-123.

Зірка В. В. Мовна парадигма маніпулятивної гри в рекламі: дис... д-ра філол. наук. НАН України; Інститут мовознавства ім. О. О. Потебні. - К., 2005. Крогиус Н. В. Познание людьми друг друга в конфликтной деятельности: дис... д-ра психол. наук. - Саратов, 1979. - 393 с.

Кубрякова Е. С. Эволюция лингвистических идей во второй половине ХХ века (опыт парадигмального анализа). Язык и наука конца 20 века; [под ред. акад. Ю. С. Степанова]. Москва : Институт языкознания РАН, 1995. - С. $144-238$.

Петлюченко Н. В. Харизматика: мовна особистість і дискурс. Одеса: «Астропринт», 2009. 464 с.

Петровская Л. А. О понятийной схеме социально-психологического исследования конфликта. Теоретические и методологические проблемы социальной психологии. - Москва : Изд-во Моск. ун-та, 1977. - С. 126-143.

Славова Л. Л. Мовна особистість лідера у дзеркалі політичної лінгвоперсонології: США - Україна: монографія. -

Житомир: Вид-во ЖДУ ім. І. Франка, 2012. - 358 с.

Таранов П. С. Приемы влияния на людей: Азбука интриги. - Симферополь: Таврия, 1995. - 493 с.

Феофанов О. А. Реклама: новые технологии в России: учебное пособие. - СПб.: Питер, 2000. - 384 с.

Фролова І. Є. Стратегія конфронтації в англомовному дискурсі: монографія. Харків: ХНУ імені В. Н. Каразіна, 2009. 344

c.

Чайка Л. В. Вербальные конфликты: вариант классификации. Вісник ДУЕП імені Альфреда Нобеля. Серія «Філологічні науки». - Дніпропетровськ: ТОВ «Роял Принт», 2011. - С. 170-174.

\footnotetext{
32 Dontsov\&Polozova 1980, 128

33 Taranov 1995, 132-143
} 
Шевченко И.С., Бондаренко Е. В., Мартынюк А. П., Фролова И. Е. Как нарисовать портрет птицы: методология когнитивно-коммуникативного анализа языка: кол. монография / под ред. И. С. Шевченко. Х.: ХНУ имени В.Н. Каразина, 2017.246 с.

Blaкar, R. М. (1979). Language as a means of social power. In: Pragmalinguistics, J. Mey (ed.). The Hague-Paris, Mouton, p. $131-169$.

Bohr, N. (1948). On the notions of causality and complementarity. In Dialectica, 2: 312-319. Also in Bohr 1996: 330-337.

Bolindger, D. (1980). Language: The Loaded Weapon. London and New York, Longman. 383 p.

Chaos and Order. Complex Dynamics in Literature and Science. (1991). [Ed. by N. K. Hayles]. Chicago: The University of Chicago Press. 318 p.

From Simplicity to Complexity. Part II. Information - Interaction - Emergence. (1998). [Ed. by K. Mainzer, A. Müller, W. G. Saltzer]. Braunschweig, Weisbaden: Vieweg. 233 p.

Grice, H. P. (1975). Logic and conversation'. In P. Cole and J. Morgan (Eds) Studies in Syntax and Semantics III: Speech Acts, New York: Academic Press. P. 83-98.

Laurindsen K. M. (1989). Principles for a syntactico-semantic analysis of the modal verbs in English and Danish. In 24 International conference on Polish-English Contrastive Linguistics. Brazejewko. P. 2-5.

Schelling, T C. (1980). The strategy of conflict. Cambridge, MA: Harvard University Press. 309 p.

Searle, J. R. (1975). Indirect speech acts. In: «Syntax and Semantics». Vol. 3. Speech Acts, Cole P., Morgan J. L. (Eds.). New York San Francisco - London, Academic Press. P. 59-82.

Sweetser, E. E. (1987). The definition of lie: an examination of the folk models underlying a semantic prototype. In Cultural models in language and thought. (Ed. by D. C. Holland and N. Quinn). Cambridge: CUP. P. 43-66.

Sweetser, E. E. (2000). Blended spaces and performativity. Cognitive Linguistics. Vol. 11. N. 3-4. P. 305-333.

Vanderveken, D. (1991). Non Literal Speech Acts and Conversational Maxims. In: E. Lepore \& R. Van Gulick, eds.: John Searle and his Critics. Oxford: Blackwell. P. 371-384.

\section{REFERENCES}

Aksyonenko, S. E. (1975). Osoznaniye konfliktnoi situatsii i obshcheniye [Осознание конфликтной ситуации и общение]. In Teoriticheskiye i prikladnye problemy psikhologii poznaniya lyudmi drug druga. Tezisy dokladov. Krasnodar: Izd-vo Kubanskogo universiteta. P. 9-11.

Antsupov, A. Ya., Shipilov, A. I. (2008). Konfliktologiya. [Конфликтология]: uchebnik dlya vuzov. 3-e izd. SPb. M. Kh. Minsk: Piter. $490 \mathrm{p}$.

Borisov, B. L. (2001).Tekhnologiya reklamy i PR: uchebnoye posobiye [Технологии рекламы и PR: учебное пособие]. M.: FAIR-PRESS. $624 \mathrm{p}$.

Borisevich, V. V. (2003). Obrazy verbal'no-konfliktnykh situatsii [Образы вербально-конфликтных ситуаций]. In Kultura narodov Prichernomor'ya. № 44. Simferopol: Tavricheskii natsional'nyi universitet im. V I. Vernadskogo. P. $186-190$.

Borisevich, V. V. (2002). Znachennya sotsial'noyi roli komunikanta v genezi verbal'nogo konfliktu [Значення соціальної ролі комуніканта в генезі вербального конфлікту]. In Mova ta istoriya: Periodychnyi zbirnyk naukovykh prats'. К. 2002. Vyp. 59. Р. $13-15$.

Chayka, L. V. (2011). Verbal'nye konflikty: variant klassifikatsii [Вербальные конфликты: вариант классификации]. In Visnyk DUEP im. Alfreda Nobelya. Seriya «Filologichni nauky». Dnipropetrovs'k: TOV «Royal Print». P. 170-174.

Dontsov, A. M., Polozova, T. A. (1980). Problema konflikta v zapadnoi sotsial'noi psikhologii [Проблема конфликта в западной социальной психологии]. In Psikhologicheskii zhurnal. Т. 1. № 6. Р. 119-123.

Feofanov, O. А. (2000). Reklama: novye tekhnologii v Rossii. [Реклама: новые технологии в России]: uchebnoye posobiye. SPb: Piter. $384 \mathrm{p}$

Frolova, I. Ye. (2009). Strategiya konfrontatsiyi v anlomovnomu dyskursi [Стратегія конфронтації в англомовному дискурсі]: monografiya. Kharkiv: KhNU imeni V. N. Karazina. 344 c.

Grice, H. P. (1975). Logic and conversation'. In P. Cole and J. Morgan (Eds) Studies in Syntax and Semantics III: Speech Acts, New York: Academic Press. P. 183-98.

Herasina, L. M., Panov, M. I., Osipova, N. P. (2002). Konfliktologiya [Конфліктологія]: navch. pos. Kharkiv: Pravo. 256 p.

Krogius, N. V. (1979). Poznaniye lyud'mi drug druga v konfliktnoi deyatel'nosti [Познание людьми друг друга в конфликтной деятельности]: dis... d-ra psikhol. nauk. Saratov. 393 p.

Kubryakova, E. S. (1995). Evolutsia lingvisticheskikh idei vo vtoroi polovine XX veka (opyt paradigmalnogo analiza) [Эволюция лингвистических идей во второй половине XX века (опыт парадигмального анализа)]. Yazyk i nauka kontsa XX veka; [ed. by akad. Yu. S. Stepanov]. M.: Institut yazykoznaniya RAN. P. 144-238.

Petrovskaya, L. A. (1977). O ponyatiinoi skheme sotsial'no-psikhologicheskogo issledovaniya konflikta [О понятийной схеме социально-психологического исследования конфликта]. In Teoriticheskiye i metodologicheskiye problemy sotsial'noi psikhologii. M.: Izd-vo Mosk. un-ta. P. 126-143.

Petlyuchenko, N.V. (2009). Kharyzmatyka: movna osobystist' i dyskurs [Харизматика: мовна особистість і дискурс]. Оdesa: «Astroprynt». $464 \mathrm{p}$.

Taranov, P. S. (1995). Priyomy vliyaniya na lyudei: Azbuka intrigi. [Приемы влияния на людей: Азбука интриги]. Simferopol: Tavriya. 493 p.

Zirka, V. V. (2005). Movna paradyhma manipulyatuvnoyi hry v reklami [Мовна парадигма маніпулятивної гри в рекламі]: dys... d-ra filol. nauk. NAN Ukrayiny; Instytut movoznavstva im. O. O. Potebni. Kyiv.

Blaкаr, R. M. (1979). Language as a means of social power. In: Pragmalinguistics, J. Mey (ed.). The Hague-Paris, Mouton, p. $131-169$.

Bolindger, D. (1980). Language: The Loaded Weapon. London and New York, Longman. 383 p.

Laurindsen, K. M. (1989). Principles for a syntactico-semantic analysis of the modal verbs in English and Danish. In 24 International conference on Polish-English Contrastive Linguistics. Brazejewko. P. 2-5. 
Searle, J. R. (1975). Indirect speech acts. In: «Syntax and Semantics», vol. 3; Speech Acts, Cole P., Morgan J. L. (Eds.). New York San Francisco - London, Academic Press. P. 59-82.

Schelling, T C. (1980). The strategy of conflict. Cambridge, MA: Harvard University Press. 309 p.

Shevchenko, I.S.; Bondarenko, E. V.; Martynyuk, A. P.; Frolova I. E. (2017). Kak narisovat' portret ptitsy: metodologiya kognitivnokommunikativnogo analiza yazyka. [Как нарисовать портрет птицы: методология когнитивно-коммуникативного анализа языка]: kol. monografiya (ed. by I. S. Shevchenko). Kh.: KhNU imeni V.N. Karazina. 246 c.

Slavova, L. L. (2012). Movna osobystist' lidera u dzerkali politychnoyi lingvopersonologiyi: USA - Ukrayina [Мовна особистість лідера у дзеркалі політичної лінгвоперсонології: США - Україна]: monographiya. Zhytomyr: Vyd-vo ZhDU im. I. Franka. 358 p.

Sweetser, E. E. (1987). The definition of lie: an examination of the folk models underlying a semantic prototype. In Cultural models in language and thought. (Ed. by D. C. Holland and N. Quinn). Cambridge: CUP. P. 43-66.

Sweetser, E. E. (2000). Blended spaces and performativity. Cognitive Linguistics. Vol. 11. N. 3-4. P. 305-333.

Vanderveken, D. (1991). Non Literal Speech Acts and Conversational Maxims. In: E. Lepore \& R. Van Gulick, eds.: John Searle and his Critics. Oxford: Blackwell. P. 371-384.

\section{Анотація}

У статті наведені результати аналізу вербальних конфліктів на матеріалі англомовного діалогічного дискурсу, висвітлені проблеми, пов'язані з їх визначенням, структурою та динамікою. У роботі розглянуто ряд питань, що стосуються вербальних конфліктів, яким властиве мовне маніпулювання, тобто використання особливостей мови і принципів іiї вживання 3 метою прихованого впливу на адресата в потрібному для мовця напрямку. У статті сформульовано поняття ситуації вербального конфлікту, схарактеризовані їі фази, складники, визначено фактичні та потенційні типи вербального конфлікту, а також окремі образи вербально- конфліктних ситуацій. У статті розглядаються уявлення комунікантів про себе й про партнерів із конфліктної мовленнєвої взаємодії з боку цілей, можливостей, соціальних характеристик та психічного стану; про середовище, у якому перебігає вербальний конфлікт; про код комунікативного акту; про канал зв'язку, за допомогою якого здійснюється комунікативна взаємодія. У роботі характеризуються два типи дій, що входять до системи протиспрямованих акцій на тлі емоційних станів, метою яких є пряме чи непряме блокування інтенцій іншого комуніканта та досягнення поставленої перед собою позамовної мети. Охарактеризовані прямий та непрямий способи виходу з ситуації вербального конфлікту. Серед різних маніпулятивних комунікативних ходів, що дозволяють непрямо вийти з вербального конфлікту без його ескалації, згадуються такі давно відомі психологам та фахівцям з теорії комунікації тактики: маскування власних намірів; відверта дезінформація супротивника; удавана згода; заманювання; вичікування; демонстрація хибних та справжніх цілей (відволікання уваги); блеф тощо. Ескалація вербального конфлікту розглядається як зіткнення на суб'єктно-діяльнісній або на особистій основі. Виділено декілька варіантів перебігу конфліктної мовленнєвої взаємодії.

Наприкінці, ми пропонуємо деякі заключні зауваження та пропозиції щодо подальших досліджень.

\section{Ключові слова}

Вербальний конфлікт, структура, динаміка, маніпуляція, адресант, адресат, комунікативний акт, канал комунікації, ескалація. 